\title{
Harnessing Agricultural Potentials for Economic Growth in North Carolina
}

\author{
Janaranjana Herath ${ }^{1} \&$ David Hill ${ }^{1}$ \\ ${ }^{1}$ Tillman School of Business, Mount Olive College, Mount Olive, North Carolina, USA \\ Correspondence: Saman Janaranjana Herath Bandara, Tillman School of Business, Mount Olive College, Mount \\ Olive, NC 28365, USA. Tel: 1-919-299-4935. E-mail: sbandara@moc.edu
}

Received: January 28, 2013 Accepted: February 28, 2013 Online Published: March 10, 2013

doi:10.5539/sar.v2n2p142 URL: http://dx.doi.org/10.5539/sar.v2n2p142

\begin{abstract}
Agriculture in North Carolina contributes to 19 percent of the state's income and employs over 20 percent of the work force. Agricultural activities are significant in rural counties and nearly 30 percent of the total population of North Carolina lives in 85 rural counties. Individuals in these rural counties have less income, education, and employment opportunities eventually in high poverty and unemployment rates. The objective of this study is to examine the potential use of agriculture in economic growth of North Carolina using county level data. Data were gathered from U.S. Bureau of Labor Statistics, U.S. Department of Agriculture, and U.S. Census Bureau for the period of 2000 to 2010. A system of simultaneous equations is used for the analysis. Results highlight that increasing income increases agricultural activities and vise versa. Thus, the counties with high household income levels are more capable of incorporating agriculture in economic growth while the counties with significant agricultural activities are more competent of improving income levels. Overall, results conclude the importance of secured satisfactory level of income through agriculture to enhance economic growth.
\end{abstract}

Keywords: agriculture, economic growth, simultaneous analysis, North Carolina

\section{Introduction}

Agriculture plays a significant role in rural economies of the United States. It creates job opportunities, supports rural development, and secures food production (Rosenberger, Gebremedhin, \& Hailu, 2002). Through processing and marketing of farm and food products, it makes significant contribution to the economy of rural communities (Rephann, 2008). The farm sector consists of small and large farms. The small family farms, which have the annual sales less than $\$ 250,000$, were 88 percent of total US farms in 2007 (U.S. Department of Agriculture [USDA], 2011b). Small farms have a lower profit than the large farms but play a significant role in rural economies (Hoppe \& Banker, 2010). The large farms were only 12 percent of total U.S. farms in 2007, but contributed to 84 percent of the total value of U.S. production (Hoppe \& Banker, 2010).

Investment in agriculture is important in economic growth. A main reason for the chronic poverty in rural areas is the lack of investment in rural communities (Duncan, 2005). Based on a study at Vietnam, Janvry and Sadoulet (2009) indicate that growth in agriculture opens pathways for poverty alleviation among farming households. A study based on evidence from Latin America and other developing regions, reveals that agricultural growth contribute to both national growth and poverty reduction that is greater than its simple share of national GDP (Valdés \& Foster, 2010). The small farm development is not only desirable for poverty reduction, but also feasible in improving food chains which uplift rural economies (Wiggins et al., 2010). A study based on survey data of 2445 Chinese Villages reveals that improving agricultural specialization and developing farmer economic organization can improve rural income significantly (Yand \& Liu, 2012). A study based on various cross-country econometric evidences indicates that agriculture is significantly more effective in reducing poverty among the poorest of the poor (Christiaensen, Demery, \& Kuhl, 2011). Enhancing rural non-farm economy with adequate opportunities for poor (RNFE) is one potential pathway of overcoming poverty among rural poor (Haggblade, Hazell, \& Reardon, 2010).

Agricultural growth benefits the urban poor by reducing food prices (Byerlee, 2000). Sometimes, urbanization and its associated policies may decline agricultural and other rural lands hindering agricultural production and environmental qualities (Rosenberger et al., 2002). Comprehensive policy implications could maintain agricultural benefits parallel to urbanization. For instance, agritourism could be enhanced with urbanization to 
generate more revenue for the rural agricultural sector (Phillips, McFadden, \& Sullins, 2011). Agritourism entrepreneurs with business plans have approximately twice as much income compared to those with no business plans for their enterprises (Phillips et al., 2011).

Enhancing the efficiency of existing agricultural productivity, agricultural research, education, extension, and technologies are important for rural economic development (van der Ploeg, 2000). Increasing the value of the product generated by the agricultural enterprise by constructing new linkages with markets strengthen the rural agricultural economy (Banks \& Marsden, 2000). Community supported agricultural farms (CSA), direct marketing, agritourism, and roadside marketing are potential niche markets for rural economic growth (Phillips, McFadden, \& Sullins, 2009). Agritourism brings significant revenues to the rural farmers in California and Colorado (Rilla, Hardesty, Getz, \& George, 2011; Phillips et al., 2011). Agricultural institutes, education and training opportunities, and developing to keep in touch with the labor markets are essential for sustainable agricultural development (Bawden, 1996).

\section{Background of the Study Area}

Agriculture is one of the significant industries in North Carolina. Agriculture industry in North Carolina contributes over $\$ 74$ billion annually to the state's economy on 19 percent of the state's income. Over 20 percent of the state's total workforce is employed in agriculture (USDA, 2011a). Nearly 8,474,671 acres of North Carolina's farmlands produce cash crops, field crops, vegetables, fruits, and other leafy vegetables (USDA, 2011a). The livestock farming in North Carolina consists of poultry, swine, and cattle. There are 85 rural counties in North Carolina representing 30 percent of the state's population (2011b). Nearly 68.5 percent of the state's population is White, 21.5 percent is Black, and 8.4 percent is of Hispanic/Latino origin (U.S. Census and Bureau, 2010). The rural North Carolina indicates a high poverty rate, and is significantly lower per capita income than urban areas (USDA, 2011b). In 2010, rural poverty rate was 20.3 percent, compared to 16.2 percent in urban areas of the state. Education level is poor in rural North Carolina with 21 percent of the rural population not completing high school, compared to 14.5 percent of urban population (American Community Survey [ACS], 2010). The rural-unemployment rate is 2 percent higher compared to urban areas (USDA, 2011b).

The objective of this study is to examine the potentials of the agricultural sector in economic growth of North Carolina, using county level data for the period of 2000 to 2010.

The paper is organized into five sections. Section 2 provides a brief account of North Carolina. Section 3 explains methodology. Section 4 describes empirical results and analysis. Section 5 presents conclusions.

\section{Methodology}

Achieving the objective of this study, a model with a system of simultaneous equations is used with three different equations for the interdependent variables of agricultural employment growth, income growth, and population growth. The model is derived based on the non-spatial simultaneous approach of Carlino and Mills (1987); later modified by Deller, Tsai, Marcouiller, and English (2001). Importantly, a system of equations estimates all the identified structural equations together as a set which minimizes asymptotic variance. Simultaneity accounts for interactions among the interdependent variables which help in overcoming inconsistency and bias, and results comprehensive and efficient estimations. Three-stage least squares (3SLS) estimation was followed for analysis.

For empirical analysis, county level data were used. The interdependent variables were income growth, employment growth, and population growth. The independent variables were derived from social factors (SF), behavioral factors (BF) and environmental factors (EF).

The variables Income ${ }^{*}$, Employment ${ }^{*}$, and Population ${ }^{*}$ represent the equilibrium levels of household income, agricultural employment, and population. $\Omega^{\mathrm{I}}, \Omega^{\mathrm{E}}$, and $\Omega^{\mathrm{P}}$ are a set of variables describing initial conditions that measure social factors $(\mathrm{SF})$, environmental factors $(\mathrm{EF}$,$) and behavioral factors (\mathrm{BF})$ that are linked to employment growth. This gives the general form of the three equations model as:

$$
\begin{aligned}
& \text { Income }^{*}=\mathrm{f}\left(\text { Employment*, Population*, } \Omega^{\mathrm{I}}\right) \\
& \text { Employment* }=\mathrm{g}\left(\text { Income*, Population*, } \Omega^{\mathrm{E}}\right) \\
& \text { Population* } \mathrm{h}\left(\text { Income*, Employment*, } \Omega^{\mathrm{P}}\right)
\end{aligned}
$$

Considering the equilibrium framework of the model, a simple liner relationship among variables can be developed as (where I is income, $\mathrm{E}$ is employment, and $\mathrm{P}$ is population):

$$
\mathrm{I}^{*}=\alpha_{\mathrm{oI}}+\beta_{1 \mathrm{I}} \mathrm{E}^{*}+\beta_{2 \mathrm{I}} \mathrm{P}^{*}+\sum \delta_{\mathrm{I}} \Omega^{\mathrm{I}}
$$




$$
\begin{gathered}
\mathrm{E}^{*}=\alpha_{\mathrm{oE}}+\beta_{1 \mathrm{E}} \mathrm{I}^{*}+\beta_{2 \mathrm{E}} \mathrm{P}^{*}+\sum \delta_{\mathrm{E}} \Omega^{\mathrm{E}} \\
\mathrm{P}^{*}=\alpha_{\mathrm{oP}}+\beta_{1 \mathrm{P}} \mathrm{I}^{*}+\beta_{2 \mathrm{P}} \mathrm{E}^{*+}+\sum \delta_{\mathrm{P}} \Omega^{\mathrm{P}}
\end{gathered}
$$

where $\alpha$ values indicate the intercepts of each equation, $\beta$ values indicate coefficient estimations of each interdependent variable and $\delta$ values indicate the coefficients of the set of variables that describe initial conditions.

Furthermore, income, employment, and population likely adjust to their equilibrium levels with substantial lags (i.e., initial conditions). Therefore, partial adjustment equations to the equilibrium levels are as:

$$
\begin{gathered}
\mathrm{I}_{\mathrm{t}}=\mathrm{I}_{\mathrm{t}-1}+\phi_{\mathrm{I}}\left(\mathrm{I}^{*}-\mathrm{I}_{\mathrm{t}-1}\right) \\
\mathrm{E}_{\mathrm{t}}=\mathrm{E}_{\mathrm{t}-1}+\phi_{\mathrm{E}}\left(\mathrm{E}^{*}-\mathrm{E}_{\mathrm{t}-1}\right) \\
\mathrm{P}_{\mathrm{t}}=\mathrm{P}_{\mathrm{t}-1}+\phi_{\mathrm{P}}\left(\mathrm{P}^{*}-\mathrm{P}_{\mathrm{t}-1}\right)
\end{gathered}
$$

The current, income, employment, and population level at time $t$ are functions of their initial conditions and the change between the equilibrium values and initial conditions with their respective speed of adjustment values. $\mathrm{I}_{\mathrm{t}-1}$, $\mathrm{E}_{\mathrm{t}-1}$, and $\mathrm{P}_{\mathrm{t}-1}$ are initial conditions of income, employment, and population. $\phi_{\mathrm{I}}, \phi_{\mathrm{E}}$, and $\phi_{\mathrm{P}}$ are the speed of adjustment coefficients related to the desired utility maximization level of income, employment, and population, correspondingly. Substituting equations 7 through 9 into equations 4 through 6 , and rearranging the model can be presented as:

$$
\begin{gathered}
\Delta \mathrm{I}=\alpha_{\mathrm{oI}}+\beta_{11} \mathrm{I}_{\mathrm{t}-1}+\beta_{2 \mathrm{II}} \mathrm{E}_{\mathrm{t}-1}+\beta_{3 \mathrm{I}} \mathrm{P}_{\mathrm{t}-1}+\mathrm{r}_{11} \Delta \mathrm{E}+\mathrm{r}_{2 \mathrm{I}} \Delta \mathrm{P}+\sum \delta_{\mathrm{I}} \Omega^{\mathrm{I}} \\
\Delta \mathrm{E}=\alpha_{\mathrm{oE}}+\beta_{1 \mathrm{E}} \mathrm{I}_{\mathrm{t}-1}+\beta_{2 \mathrm{E}} \mathrm{E}_{\mathrm{t}-1}+\beta_{3 \mathrm{E}} \mathrm{P}_{\mathrm{t}-1}+\mathrm{r}_{1 \mathrm{E}} \Delta \mathrm{I}+\mathrm{r}_{2 \mathrm{E}} \Delta \mathrm{P}+\sum \delta_{\mathrm{E}} \Omega^{\mathrm{E}} \\
\Delta \mathrm{P}=\alpha_{\mathrm{oP}}+\beta_{1 \mathrm{P}} \mathrm{I}_{\mathrm{t}-1}+\beta_{2 \mathrm{P}} \mathrm{E}_{\mathrm{t}-1}+\beta_{3 \mathrm{P}} \mathrm{P}_{\mathrm{t}-1}+\mathrm{r}_{11} \Delta \mathrm{I}+\mathrm{r}_{2 \mathrm{I}} \Delta \mathrm{E}+\sum \delta_{\mathrm{P}} \Omega^{\mathrm{P}}
\end{gathered}
$$

where $\Delta \mathrm{I}, \Delta \mathrm{E}$, and $\Delta \mathrm{P}$ are the changes in household income, agricultural employment, and population, correspondingly at county level. The speed of adjustment coefficients become embedded in the linear estimated parameters $\alpha, \beta, \mathrm{r}$ and $\delta$ and the model captures structural relationships. Equations 10-12 estimate short-term adjustments of income, employment, and population $(\Delta \mathrm{I}, \Delta \mathrm{E}$, and $\Delta \mathrm{P})$ to their long-term equilibriums $\left(\mathrm{I}^{*}, \mathrm{E}^{*}\right.$, and $\left.\mathrm{P}^{*}\right)$.

\section{Data}

County-level data for the period of 2000 to 2010 for all counties of North Carolina are used for analysis. Data were collected from Bureau of Economic Analysis, U.S. Bureau of Labor Statistics, U.S. Department of Agriculture, and County and City Data Books (C \& CDB). Definitions of all variables used for the analysis are presented in Table 1 with mean, minimum, and maximum value.

According to the Table $1 \Delta \mathrm{POP}$ presents the percentage change of population; $\Delta \mathrm{INC}$ presents percentage change of income, and $\triangle E M P$ represents percentage change of agricultural employment for the period of 2000 to 2010 at county level. Table shows that percentage of population has increased by 5 percent, average annual household income has increased by 5 percent, and percentage of agricultural employments has decreased by 6 percent from 2000 to 2010.

POP2000 and POP2010 present average county level population for 2000 and 2010. INC2000 and INC2010 present county level average household income for the same years. Number of people engaged in agricultural employments for 2000 and 2010 are indicated by EMP2000 and EMP2010. POP2000, INC2000, and EMP2000 are the initial values of the interdependent variables.

NIFFM2007 presents the number of individual or family owned farms for 2007. This independent variable measures the impact of farm ownership on economic growth. FSIZE2007 presents farm size in acres for 2007. This variable measures the farm size impact on employment growth. For instance, when farm size decreases potential growth of employment may decrease. The argument is supported by the study of Ikerd (2000) which highlights the realities of small farms. CRME2008 presents average number of crimes in 2008. This captures the impact of crime rate on economic growth. Crime acts like a tax on the entire economy and it discourages investments, competitiveness, and reallocates resources while creating uncertainty and inefficiency of an economy (Detotto \& Otranto, 2010). EDUC2000 presents the percentage of population 25 years or more with at least a college degree. It is experienced that people deviates from farming and agriculture with higher education: 'rural brain drain' (Artz, 2003). Thus, EDUC2000 attempts to incorporate that impact into the analysis. PNFE2010 presents the private nonfarm establishments for 2010 and OEMP2001 presents availability of employments other than farm employments for 2001. Higher levels of both variables can increase employment opportunities other than agricultural employments (Lanjouw \& Lanjouw, 2001). LATN2000 presents average 
number of Hispanic population for 2000 and PWTE2000 presents the percentage of white population. Both variables measure the impacts of demographic characteristics.

All variables used for the analysis were tested for their correlation, mulitcollinearity, identification and others to minimize errors. Certain other variables like, percentage of poverty, number of total farms, average income per farm, and federal expenses were considered for analysis, but dropped after testing. The statistical package of STATA 9.0 was used for econometric estimation.

Table 1. Definition for county level variables

\begin{tabular}{lllll}
\hline Variable & Definition & Mean & Min & Max \\
\hline$\Delta$ POP & Percentage of population change & 5.1 & -2.1 & 21.1 \\
$\Delta$ INC & Percentage of income change & 4.8 & -2.7 & 13.5 \\
$\Delta$ EMP & Percentage of agricultural employment change & -6.1 & -26.0 & 0 \\
POP2010 & Population in 2010 & 95355 & 4407 & 919628 \\
POP2000 & Population in 2000 & 80493 & 4149 & 695454 \\
INC2010 & Average household income in 2010 & 39750 & 27421 & 63770 \\
INC2000 & Average household income in 2000 & 35493 & 25864 & 58099 \\
EMP2010 & Agricultural employment in 2010 (farming, agriculture, & 731 & 0 & 2526 \\
& fishing, forest and hunting) & & & \\
EMP2000 & Agricultural employment in 2001 (farming, agriculture, & 838 & 0 & 2858 \\
& fishing, forest and hunting) & 529 & 7 & 1501 \\
NIFM2007 & Number of individual or family owned farms 2007 & 212 & 57 & 792 \\
FSIZE2007 & Average size of a farm in acres 2007 & 427 & 4 & 7404 \\
CRME2008 & Average number of crimes in 2008 & 17 & 8 & 51 \\
EDUC2000 & Percentage of population 25 years or more with college & 17 & & \\
& degree & 2038 & 79 & 24245 \\
PNFE2010 & Private nonfarm establishments in 2010 & 47926 & 1322 & 615752 \\
OEMP2001 & Employments other than farm employments 2001 & 4277 & 93 & 58948 \\
LATN2010 & Average number of Hispanic population 2010 & 75.2 & 35 & 98.5 \\
PWTE2000 & Percentage of white population 2000 & & & \\
\hline & & & & \\
\hline
\end{tabular}

\section{Results and Discussion}

The empirical results for the system of simultaneous equations are presented in Table 2. The first column of the table indicates exogenous variables used in each equation. Columns 2 and 3 indicate results for the population change $(\triangle \mathrm{POP})$ equation while columns 4 and 5 present results for income change $(\Delta \mathrm{INC})$. Results for the agricultural employment change ( $\triangle \mathrm{EMP}$ ) equation are shown in columns 6 and 7.

According to the results for population change $(\triangle \mathrm{POP})$ in columns 2 and 3 , income change $(\Delta \mathrm{INC})$ is significantly and positively related with population. A 1 percent increase in income change $(\triangle I N C)$ increases population change $(\triangle \mathrm{POP})$ by 2.2 percent. This can be explained with migration from other regions and foreign countries. Economic Index of 2011 (North Carolina Department of Commerce, 2011) indicates that the main reason of population growth in North Carolina is migration. Results show that population change $(\triangle \mathrm{POP})$ is significantly and positively related with agricultural employment change ( $\triangle \mathrm{EMP})$. A 1 percent change (decrease) in agricultural employment change ( $\triangle \mathrm{EMP})$ increases population change $(\triangle \mathrm{POP})$ by 1.1 percent. This may be associated with different reasons. One possible explanation could be suburban sprawl which reduces direct agricultural employments and subsequently increases population growth with availability of other facilities. The result is supported by the findings of Hartgen (2003). Number of individual or family owned farms (NIFFM2007) had a positive impact on increasing population in North Carolina. This may be associated with increasing 'family labor' to maintain family or individually owned farm business that prevents migrated 'hired labor'. Average farm size in 2007 (FSIZE2007) indicates that large farm size has decreased population growth in North Carolina. This 
is an unexpected result under certain circumstances, but could be associated with high potential of replacing machinery for human labor with increasing farm size (increasing economics of scale). The result is supported by the findings related to agricultural mechanization of Takeshima and Salau (2010). Availability of employments other than farm employments (OEMP2001) indicates a positive and significant relationship with population change ( $\triangle \mathrm{EMP})$. This could expect with the creation of more job opportunities.

Results for income change $(\triangle \mathrm{INC})$ are in columns 4 and 5 . The significant and positive relationship between income change $(\triangle \mathrm{INC})$ and population change $(\triangle \mathrm{POP})$ indicates that a 1 percent increase in population increases income by 0.51 percent. This is associated with more employment generation with increasing population. The agricultural employment change ( $\triangle \mathrm{EMP}$ ) indicates that 1 percent decrease of agricultural employments decreases income growth $(\triangle \mathrm{INC})$ by 0.60 percent. This implies the potential of increasing income earnings through agricultural activities, especially in agri-based counties. Number of individual or family owned farms (NIFFM2007) had a negative impact on income change $(\Delta \mathrm{INC})$ in North Carolina. This could be associated with more time engaged in farm owners' activities that reduces the opportunities for other non-farm income earnings. Most of the small farm owners' spend much of their time on farming (Ikerd, 2000). Sometimes family operating farms might have abandoned marginal profits. Results for average farm size (FSIZE2007) indicate that large farm size has increased income growth $(\triangle \mathrm{INC})$ in North Carolina. This could expect with better economics of scale with increasing farm sizes, which may lead to higher profit margins. Result for PNFE2010 indicates that private nonfarm establishments for 2010 have not contributed well on income growth $(\Delta \mathrm{INC})$ of North Carolina.

Table 2. The results of empirical model

\begin{tabular}{|c|c|c|c|c|c|c|}
\hline \multirow[t]{2}{*}{ Variable } & \multicolumn{2}{|l|}{$\Delta \mathbf{P O P}$} & \multicolumn{2}{|l|}{$\Delta \mathbf{I N C}$} & \multicolumn{2}{|l|}{$\Delta \mathbf{E M P}$} \\
\hline & Coef. & $\mathrm{P}>|\mathrm{Z}|$ & Coef. & $\mathrm{P}>|\mathrm{Z}|$ & Coef. & $\mathrm{P}>|\mathrm{Z}|$ \\
\hline$\Delta \mathrm{POP}$ & & & $0.519755 * * *$ & 0.00 & $0.786721^{* * *}$ & 0.01 \\
\hline$\triangle \mathrm{INC}$ & $2.210856 * * *$ & 0.00 & & & $-1.939558 * * *$ & 0.01 \\
\hline$\Delta \mathrm{EMP}$ & $1.141707 * * *$ & 0.00 & $-0.601202 * * *$ & 0.00 & & \\
\hline POP2000 & 0.000002 & 0.80 & & & & \\
\hline INC2000 & & & -0.000001 & 0.44 & & \\
\hline EMP2000 & & & & & 0.000001 & 0.86 \\
\hline NIFM2007 & $0.000041 * *$ & 0.03 & $-0.000196 * * *$ & 0.00 & $-0.000040 * * *$ & 0.00 \\
\hline FSIZE2007 & $-0.000118^{* *}$ & 0.02 & $0.000060^{* * *}$ & 0.00 & $0.000105^{* *}$ & 0.03 \\
\hline CRME2008 & -0.000004 & 0.44 & & & & \\
\hline EDUC2000 & & & -0.000160 & 0.25 & & \\
\hline PNFE2010 & & & $-0.000002 * * *$ & 0.00 & & \\
\hline OEMP2001 & $0.000001^{*}$ & 0.10 & & & $-0.000001^{* * *}$ & 0.01 \\
\hline PWTE2000 & 0.000065 & 0.59 & & & & \\
\hline LATN2010 & & & & & 0.000001 & 0.20 \\
\hline
\end{tabular}

No. Obs $=100 ; \mathrm{R}^{2}$ value: $\Delta \mathrm{POP}=0.42 ; \Delta \mathrm{INC}=0.81 ; \Delta \mathrm{EMP}=0.52$.

$\mathrm{Chi}^{2}$ value: $\Delta \mathrm{POP}=190.92 ; \Delta \mathrm{INC}=498.67 ; \Delta \mathrm{EMP}=285.30$

$* * *, * *, *$ are significant at $1 \%, 5 \%$ and $10 \%$ respectively.

The results for the agricultural employment change in columns 6 and 7 (AEMP) indicate that 1 percent increase in population growth decreases agricultural employment change ( $\triangle \mathrm{EMP}$ ) by 0.78 percent. This may be associated with urban and suburban sprawl that may limit farming, agriculture, forestry, fishing and hunting. This also could be related to aging agricultural population. According to USDA (2011b) more than half of agricultural operators are more than 55 years old and involvement of young generation in agriculture is poor. Results for the income change $(\triangle \mathrm{INC})$ indicate that a one percent increase in income change decreases employment reduction in agricultural sector $(\triangle \mathrm{EMP})$ by 1.9 percent. This means increasing household income increases agricultural employments. This could be associated with high potential of risk taken linked to 
agriculture with adequate income sources. Sometimes, this may be associated with inadequate family labor for agriculture or inadequate income to hire labors. However, the result highlights the potential of incorporating agricultural activities in booming economies of some counties with secured minimum levels of household income. Number of individual or family owned farms (NIFFM2007) indicates negative relationship with employment change ( $\triangle \mathrm{EMP})$. The higher the number of individual or family owned farms decreased employment reduction. This may be related with decision making power of hiring labor with the ownership. Result for average farm size (FSIZE2007) indicates that large farm size has increased employment reduction $(\triangle \mathrm{EMP})$ in North Carolina. This could be related to more mechanization with increasing farm size. Availability of employments other than farm employments (OEMP2001) has decreased employment reduction ( $\triangle \mathrm{EMP})$ in North Carolina. However the impact is low.

\section{Conclusions}

The study attempted to examine the use of agricultural sector in economic growth of North Carolina using a system of simultaneous equations. County level data for the period of 2000 to 2010 were used for the analysis.

The results highlight that population growth hinders agricultural employments. This may be associated with urban and suburban sprawl. Even though population growth is highly related with in-migration and immigration, (Economic Index of 2011: North Carolina Department of Commerce, 2011) it may not be highly related to fulltime employment growth in agriculture. However, it needs further research to conclude that.

Interestingly, results summarize that increasing income increases agricultural activities and vise versa. Thus, the counties with high household income levels are more capable of incorporating agriculture in economic growth. Also, the counties with significant agricultural activities are more competent of improving income levels. This implies the importance of secured satisfactory level of income through agriculture. This can be achieved in many ways. One way is to improve agricultural channels of production, processing, and marketing. Another way is to identify niche markets such as agro-tourism, organic farming, farmers' market, and improving information technology (USDA, 2009). For instance, agritourism brings significant revenues to the rural farmers while creating job opportunities to farm family members (Rilla et al., 2011; Phillips et al., 2011). According to USDA (2009) California farms reported a total of \$35 million revenue related to agritourism in 2007.

However, identification and implementation of proper policy options with clear understanding of the prevailing challenges, and policy decisions taken together with farmers is important to yield the potential benefits of agriculture in economic growth.

\section{Acknowledgments}

The research was supported by funds appropriated to the Tillman School of Business, Mount Olive College.

\section{References}

American Community Survey [ACS]. (2010). Data Products Descriptions. Retrieved from http://www.census.gov/acs/www/data_documentation/product_descriptions/

Artz, G. (2003). Rural Area Brain Drain: Is It a Reality? CHOICES: The magazine of food, farm and resource issues. Retrieved from http://www.choicesmagazine.org/2003-4/2003-4-03.pdf

Banks, J., \& Marsden, T. (2000). Integrating Agri-environment Policy, Farming Systems and Rural Development: Tir Cyme in Wales. Sociologia Ruralis, 440(4), 438-466.

Bawden, R. (1996). A Learning Approach to Sustainable Agriculture and Rural Development: Reflections from Hawkesbury. University of Western Sydney, Hawkesbury, Richmond, NSW 2753, Australia.

Byerlee, D. (2000). Targeting Poverty Alleviation in Priority Setting for Agricultural Research. Food Policy, 25, 429-445. http://dx.doi.org/10.1016/S0306-9192(00)00021-X

Carlino, G. A., \& Mills, E. S. (1987). The Determinants of County Growth. Journal of Regional Science, 27(1), 25-49. http://dx.doi.org/10.1111/j.1467-9787.1987.tb01143.x

Christiaensen, L., Demery, L., \& Kuhl, J. (2011). The (evolving) role of agriculture in poverty reduction-An empirical perspective. Journal of Development Economics, 96(2), 239-254 http://dx.doi.org/10.1016/j.jdeveco.2010.10.006

Deller, S. C., Tsai, T. H., Marcouiller, D. W., \& English, D. B. K. (2001). The Role of Amenities and Quality of Life in Rural Economic Growth. American Journal of Agriculture Economics, 83(2), 352-365. http://dx.doi.org/10.1111/0002-9092.00161

Detotto, C., \& Otranto, E. (2010). Does Crime Affect Economic Growth? KYKLOS, 63(3), 330-345. 
http://dx.doi.org/10.1111/j.1467-6435.2010.00477.x

Duncan, C. M. (2005). Why Poverty Persists in Appalachia. Retrieved from http://www.pbs.org/wgbh/pages/frontline/countryboys/readings/duncan.html

Haggblade, S., Hazell, P., \& Reardon, T. (2010). The Rural Non-farm Economy: Prospects for Growth and

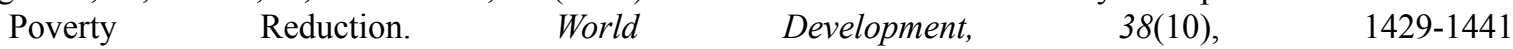
http://dx.doi.org/10.1016/j.worlddev.2009.06.008

Hoppe, R. A., \& Banker, D. E. (2010). Structure and Finances of U.S. Farms: Family Farm Report, 2010 Edition. Economic Information Bulletin No. (EIB-66) 72.

Ikerd, J. (2000). Small Farms: Perceptions versus Realities. Small Farm Today Magazine. Retrieved from http://www.smallfarmtoday.com/the-magazine.html

Janvry, A., \& Sadoulet, E. (2009). The World Bank Research Observer Advance Access published November 9, 2009, Retrieved from http://wbro.oxfordjournals.org/content/early/2009/11/09/wbro.lkp015.full.pdf + html

Lanjouw, J. O., \& Lanjouw, P. (2001). The rural non-farm sector: issues and evidence from developing countries. Agricultural Economics, 26, 1-23. http://dx.doi.org/10.1111/j.1574-0862.2001.tb00051.x

Phillips, M., McFadden, D. T., \& Sullins. M. (2009). Social Networking and Marketing for Colorado's Agricultural Producers. Department of Agricultural and Resource Economics, Fort Collins. USA.

Phillips, M., McFadden, D. T., \& Sullins. M. (2011). Possible Roles for Social Networking in Agritourism Development. Department of Agricultural and Resource Economics, Fort Collins, CO 80523-1172 http://dare.colostate.edu/pubs

Rephann, T. J. (2008). The Economic Impact of Agriculture and Forestry on the Commonwealth of Virginia, Weldon Cooper, Center for Public Service, University of Virginia. Retrieved from http://www.coopercenter.org/publications/all?tid=345

Rilla, E., Hardesty, S. D., Getz, C., \& George. H. (2011). California Agritourism Operations and their Economic Potential are Growing. Retrieved from http://californiaagriculture.ucanr.org

Rosenberger, R. S., Gebremedhin, T. G., \& Hailu, Y. (2002). An Economic Analysis of Urbanization of Agricultural Land in West Virginia. Research paper 2002-8: Division of Resource Management, West Virginia University.

Takeshima, H., \& Salau, S. (2010). Agricultural Mechanization and the Smallholder Farmers in Nigeria, Nigeria Strategy Support Program, Policy Note No. 22. Retrieved from http://www.ifpri.org/sites/default/files/publications/nssppn22_0.pdf

U. S. Department of Agriculture. (2009). Income From Farm-Related Sources: 2007 State Data. National Agricultural Statistics Service. Washington, DC. Retrieved from www.agmrc.org/commodities_products/agritourism

U. S. Department of Agriculture. (2011a). Agricultural Statistics, Retrieved from http://www.nass.usda.gov/

U. S. Department of Agriculture. (2011b). Farm Household well-being. Retrieved from http://www.ers.usda.gov/topics/farm-economy/farm-household-well-being/farm-household-income.aspx\#in come

Valdés, A., \& Foster, W. (2010). Reflections on the Role of Agriculture in Pro-Poor Growth. World Development, 38(10), 1362-1374. http://dx.doi.org/10.1016/j.worlddev.2010.06.003

Van der Ploeg, J. D. (2000). Revitalizing agriculture: Farming Economically as Starting Ground for Rural Development. Sociologia Ruralis, 40(4), 497-511. http://dx.doi.org/10.1111/1467-9523.00163

Wiggins, S., Kristen, J., \& Llambí, L. (2010). The Future of Small Farms. World Development, 38(10), 1341-1348. http://dx.doi.org/10.1016/j.worlddev.2009.06.013

Yand, D., \& Liu, Z. (2012). Does farmer economic organization and agricultural specialization improve rural income? Evidence from China. Economic Modelling, 29(3), 990-993 http://dx.doi.org/10.1016/j.econmod.2012.0 2.007 